\title{
Electron Microscopy of Adhesive Interactions between Gardnerella vaginalis and Vaginal Epithelial Cells, McCoy Cells and Human Red Blood Cells
}

\author{
By THOMAS G. SCOTT, ${ }^{1 *}$ BERNADETTE CURRAN ${ }^{2}$ AND \\ CYRIL J. SMYTH ${ }^{3}$ \\ ${ }^{1}$ Department of Biological Sciences, Dublin Institute of Technology, Kevin St, Dublin 8, \\ Republic of Ireland \\ ${ }^{2}$ Department of Pathology, St James's Hospital, Dublin 8, Republic of Ireland \\ ${ }^{3}$ Department of Microbiology, Moyne Institute, Trinity College, Dublin 2, Republic of Ireland
}

(Received 11 October 1988; accepted 16 November 1988)

\begin{abstract}
Exfoliated vaginal epithelial cells with attached bacteria, termed 'clue cells', which were procured from a patient with non-specific vaginitis, were stained with ruthenium red and examined by transmission electron microscopy. The attached bacteria appeared to adhere by means of an outer fibrillar coat. An epithelial tissue culture cell line (McCoy) and human red blood cells to which strains of Gardnerella vaginalis attached were similarly examined. The adherence of $G$. vaginalis to the epithelial cell line appeared to be mediated by an outer fibrillar coat while adherence to red cells appeared to be mediated by fimbriae. Transmission electron microscopy was performed on the Gardnerella strains used. Thin sections of tissue-cultureadherent strains revealed a dense outer fibrillar coat whereas the surface of the haemagglutinating strains showed fine fimbriae. Negative staining of haemagglutinating strains demonstrated fimbriae on a minority of organisms.
\end{abstract}

\section{INTRODUCTION}

The role of Gardnerella vaginalis in bacterial vaginosis has been a matter of controversy (Amsel et al., 1983; Easmon \& Ison, 1986). A common feature of many studies has been the presence of so-called 'clue cells' (exfoliated vaginal epithelial cells coated with Gram-variable bacilli) in the vaginal discharges of patients with bacterial vaginosis (Amsel et al., 1983). In the evaluation of the role of $G$. vaginalis, the adhesive properties of this organism are generating increasing interest (Mårdh \& Weström, 1976; Sobel et al., 1981; Ison \& Easmon, 1985; Peeters \& Piot, 1985; Scott et al., 1987; Scott \& Smyth, 1987).

The adhesive properties have been investigated using human red blood cells (Ison \& Easmon, 1985) and vaginal epithelial cells (Mårdh \& Weström, 1976; Sobel et al., 1981; Peeters \& Piot, 1985). However, in a recent study (Scott \& Smyth, 1987) it was shown that separate adhesin receptor systems were involved in the attachment of $G$. vaginalis strains to human red cells and to an epithelial cell line (McCoy). The adhesins involved appeared to be protein in nature (Peeters \& Piot, 1985; Scott \& Smyth, 1987), but the type of bacterial surface structure involved was not reported.

Transmission electron microscopy of G. vaginalis has been reported (Reyn et al., 1966; Crisswell et al., 1972; Greenwood, 1983). Evidence of fibrillar material adhering to the cell wall has been found (Crisswell et al., 1972; Greenwood, 1983). Fimbriae have also been revealed on G. vaginalis strains (Johnson \& Davies, 1984; Boustouller et al., 1987), but so far there is no evidence for their role in haemagglutination or epithelial cell adhesion.

The purpose of the present study was to examine the morphological nature of attachment of presumptive $G$. vaginalis to 'clue cells' and to compare this with attachment of $G$. vaginalis strains to human red cells and tissue culture cells (McCoy cells) as model systems to determine whether or not apparently similar adherence systems were involved. 


\section{METHODS}

Bacterial strains and growth conditions. Strains of $G$. vaginalis used were identified according to the criteria of Taylor \& Phillips (1983). Two tissue-culture-adherent strains, 25 and 26, and two haemagglutinating strains, 102 and 624, were used; they were acquired during a study on the tissue culture adherence and haemagglutinating properties of G. vaginalis (Scott et al., 1987; Scott \& Smyth, 1987). The tissue culture adherence indices (Scott et al., 1987) for strains 25 and 26 were $88 \%$ and $96 \%$, respectively. Relative haemagglutination of strains 102 and 624 was +++ for each (Scott \& Smyth, 1987). Bacteria were grown on Casman blood agar at $37{ }^{\circ} \mathrm{C}$ in $5 \%(v / v) \mathrm{CO}_{2}$ for $48 \mathrm{~h}$ prior to testing. The strains used had been passaged 15-20 times prior to testing.

Transmission electron microscopy. Clue cells were collected from a patient with non-specific vaginitis by taking two swabs. One was fixed for $2 \mathrm{~h}$ in $3 \%(\mathrm{v} / \mathrm{v})$ glutaraldehyde in $0.2 \mathrm{M}$-cacodylate buffer $(\mathrm{pH} 7 \cdot 3$ ) mixed with an equal volume of ruthenium red $\left(4 \mathrm{mg} \mathrm{ml}^{-1}\right.$ in distilled water). The cell suspension was centrifuged, washed in cacodylate buffer and fixed in $5 \%(\mathrm{w} / \mathrm{v}) \mathrm{OsO}_{4}, 0.2 \mathrm{M}$-cacodylate buffer $(\mathrm{pH} 7 \cdot 3)$ and ruthenium red $\left(4 \mathrm{mg} \mathrm{ml}^{-1}\right)$ in equal volumes for $3 \mathrm{~h}$. The preparation was then dehydrated and embedded. The second swab was cultured by routine diagnostic methods for Neisseria gonorhoeae, Candida albicans and G. vaginalis. A smear was examined for clue cells using Gram stain. Only $G$. vaginalis was isolated and clue cells were present. This isolate was not used in the present in vitro studies.

For the examination of bacteria adhering to tissue culture cells, suspensions of bacteria containing $3 \times 10^{8}$ c.f.u. $\mathrm{ml}^{-1}$ in Dulbecco PBS, $\mathrm{pH} 7 \cdot 2$, were added to McCoy cells in $25 \mathrm{ml}$ tissue culture flasks prepared as described previously (Scott et al., 1987) and incubated for $1 \mathrm{~h}$ at $37^{\circ} \mathrm{C}$. The monolayer was washed five times in buffer and the cell sheet was removed. Adherence to red cells was examined by adding equal volumes of suspensions of bacteria $\left(5 \times 10^{10} \mathrm{c}\right.$.f.u. $\left.\mathrm{ml}^{-1}\right)$ to $3 \%(\mathrm{v} / \mathrm{v})$ suspensions of packed human red blood cells in test tubes at $0{ }^{\circ} \mathrm{C}$ for $5 \mathrm{~min}$. The resulting agglutinated red cells were sedimented at $200 \mathrm{~g}$ for $2 \mathrm{~min}$. Both tissue culture cell deposits and red cell deposits were fixed and treated as described above.

For the examination of bacteria, suspensions were prepared in distilled water and washed twice. The suspensions were centrifuged in an Eppendorf centrifuge for $5 \mathrm{~min}$. The deposits were fixed and treated as described. Strain 26 was treated with pronase E $\left(2 \mathrm{mg} \mathrm{ml}^{-1}\right.$, Sigma $)$ at $37^{\circ} \mathrm{C}$ for $2 \mathrm{~h}$, washed in Dulbecco PBS and similarly treated. Sections were cut of the various preparations on an LKB Ultratome III. Routinely, 30 bacteria per grid were examined.

Negative staining. Bacterial cells were suspended in distilled water until faintly turbid. A carbon-Formvarcoated grid was floated on a drop of suspension for $1 \mathrm{~min}$. The excess fluid was removed by blotting and the grid was floated on a drop of $2 \%(\mathrm{w} / \mathrm{v})$ sodium silocotungstate $(\mathrm{pH} 7 \cdot 2)$ for $20 \mathrm{~s}$. The excess fluid was removed and the grid was air dried. Routinely, 30 bacteria per grid were examined. All preparations were examined on a Jeol 100 CX transmission electron microscope.

\section{RESULTS}

Clue cells. Thin sections of the vaginal discharge showed the attachment of large numbers of Gardnerella-like organisms to the exfoliated vaginal epithelial cells (Fig. $1 a$ ). The attachment appeared to be mediated by a dense outer fibrillar coat which was $60-75 \mathrm{~nm}$ in thickness (Fig. 1 b).

McCoy cells. The two tissue-culture-adherent strains 25 and 26 showed evidence of attachment to the McCoy cells by means of a similar $60-75 \mathrm{~nm}$ outer fibrillar coat (Fig. $1 \mathrm{c}$ ) to that observed in the attachment of Gardnerella-like organisms to the exfoliated vaginal epithelial cells. All the Gardnerella cells adhering to the McCoy cells possessed a fibrillar coat. Occasionally thin strands resembling fimbriae were seen between adhering bacteria and the McCoy cell surface (Fig. 1c).

Human red blood cells. Haemagglutinating strains 102 and 624 were observed to attach to the red cell surface by means of fimbriae (Fig. 2). These varied in length from 800 to $1200 \mathrm{~nm}$. Almost all the bacteria adjacent to the red cells showed numerous peritrichous fimbriae on their surface. There was no evidence of attachment to the red cell surface by means of an outer fibrillar coat as seen in the case of McCoy cells and clue cells.

G. vaginalis strains. Thin sections of the two tissue-culture-adherent strains 25 and 26 showed the presence of an outer fibrillar coat (Fig. $3 a$ ). Thirty bacteria of each strain were examined and over $90 \%$ showed evidence of this outer coat. After treatment with pronase strain 26 did not adhere to McCoy cells. The outer fibrillar coat was removed by this treatment (Fig. $3 b$ ). In 

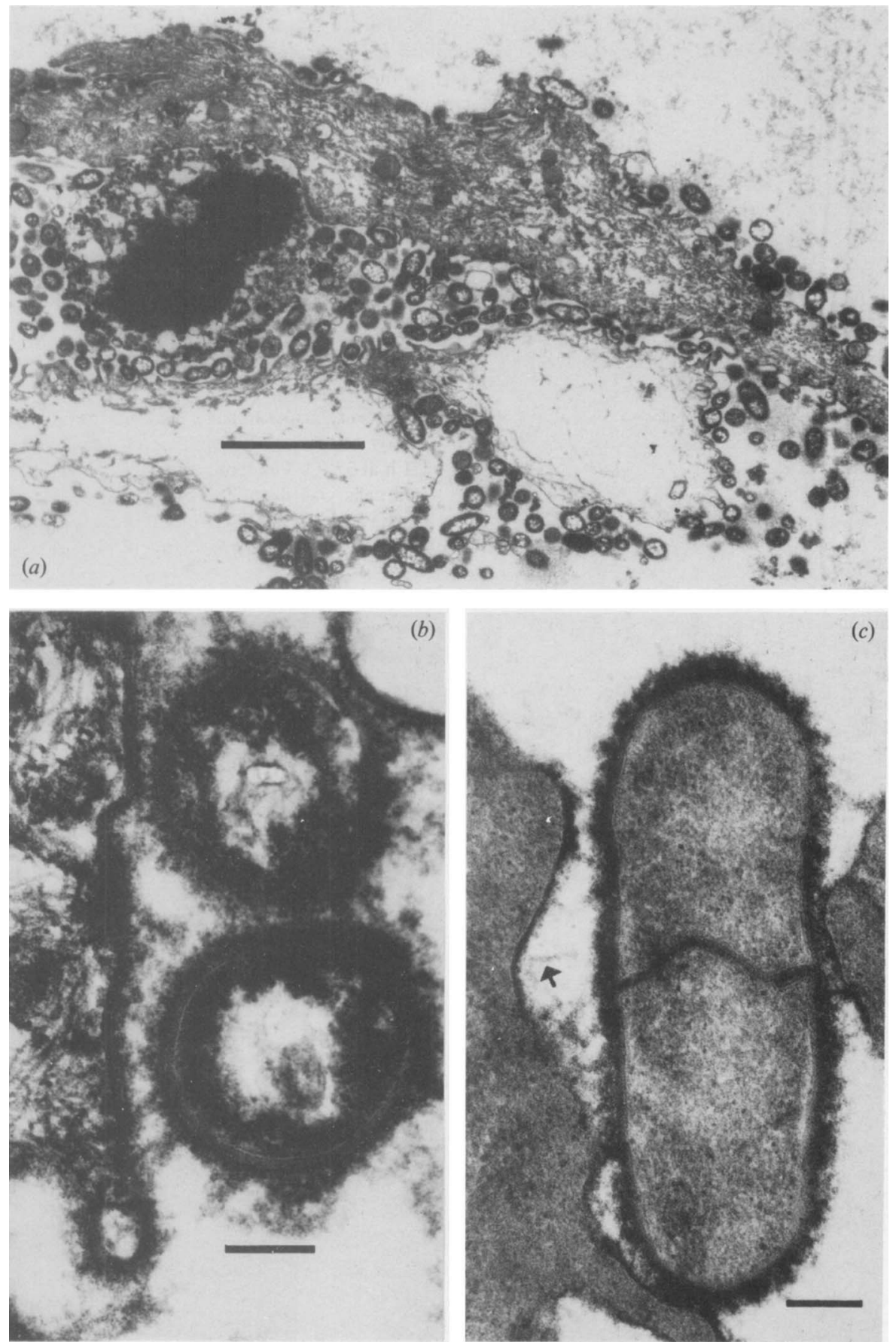

Fig. 1. This sections of the in vivo attachment of Gardnerella-like organisms to an exfoliated vaginal epithelial cell (clue cell) $(a, b)$, and of $G$. vaginalis strain 26 attached to a McCoy cell in vitro $(c)$. Note the fibrillar coat on the adherent bacteria in $(b)$ and $(c)$. An occasional fimbrial structure was seen (arrowed in $c$ ). The preparations were stained during fixation with ruthenium red. Bars, $10 \mu \mathrm{m}(a)$ and $0.4 \mu \mathrm{m}(b)$ and $(c)$. 


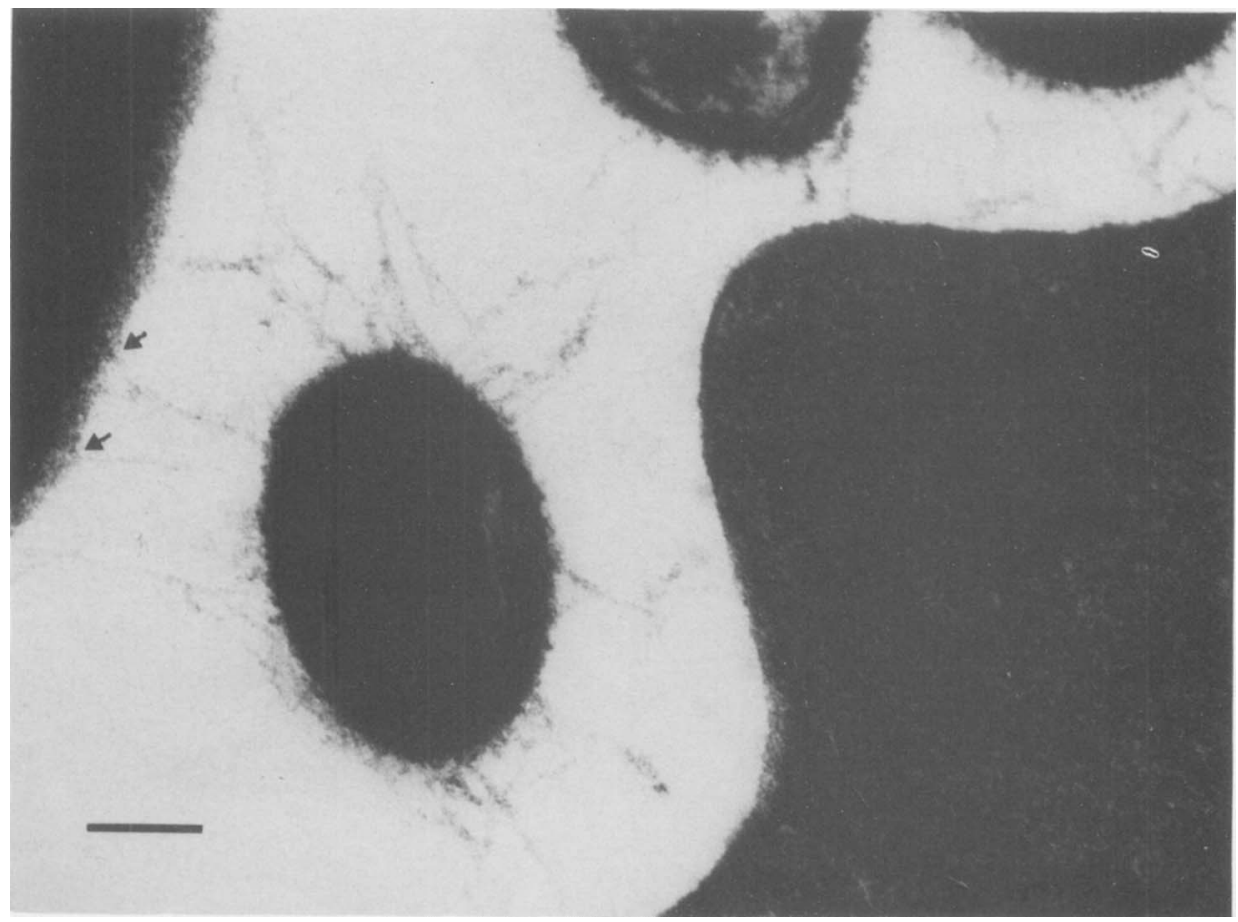

Fig. 2. Thin section of human red blood cells agglutinated by G. vaginalis strain 624 . Adhesion to red cells was by numerous fimbriae radiating from the bacterial cell. The tips of fimbriae can be seen to make contact with erythrocyte membrane (arrows). The preparation was stained during fixation with ruthenium red. Bar, $0.5 \mu \mathrm{m}$.
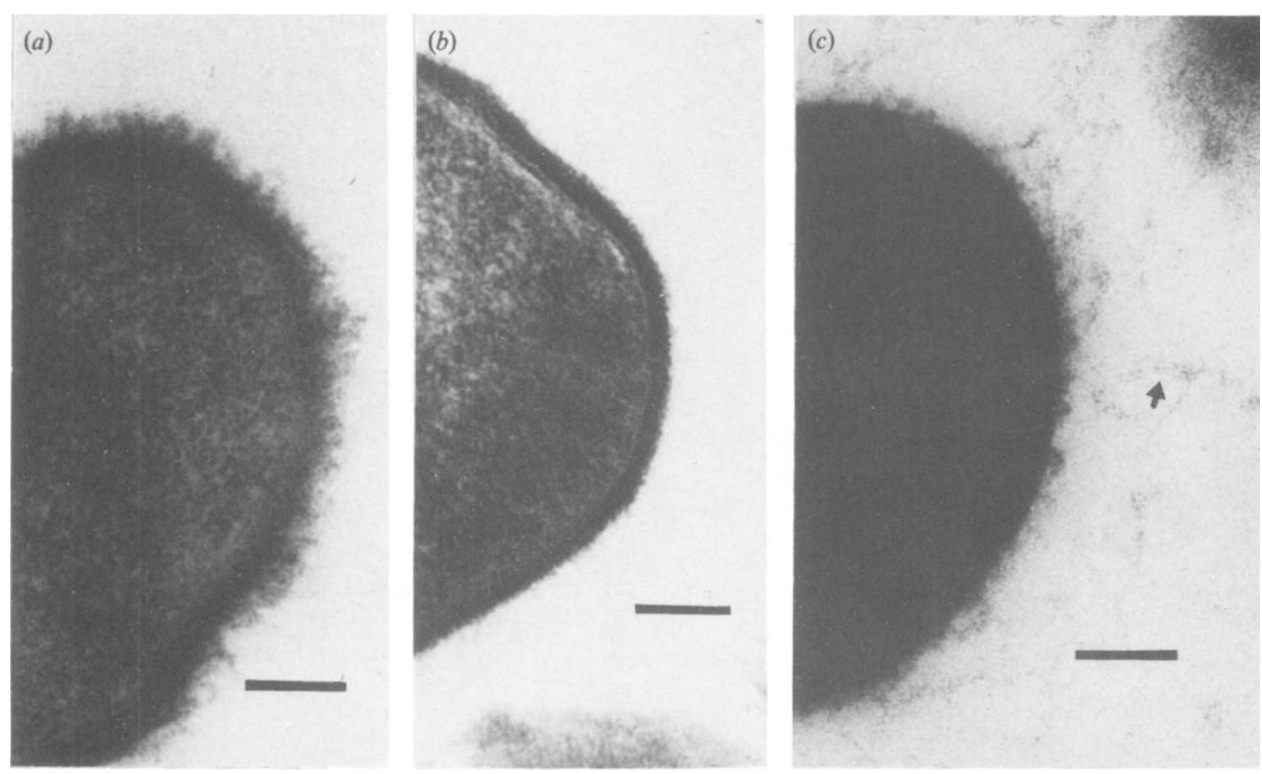

Fig. 3. Thin sections showing cell surface structure of $G$. vaginalis strains. (a) Tissue-culture-adherent strain 26 showing outer fibrillar surface coat; $(b)$ strain 26 treated with pronase $\mathrm{E}$ - note the absence of outer fibrillar coat; $(c)$ haemagglutinating strain 624 - note the absence of outer fibrillar coat (cf. $a$ ) and the presence of thin fimbriae (arrow). The preparations were stained during fixation with ruthenium red. Bar, $0 \cdot 2 \mu \mathrm{m}$. 

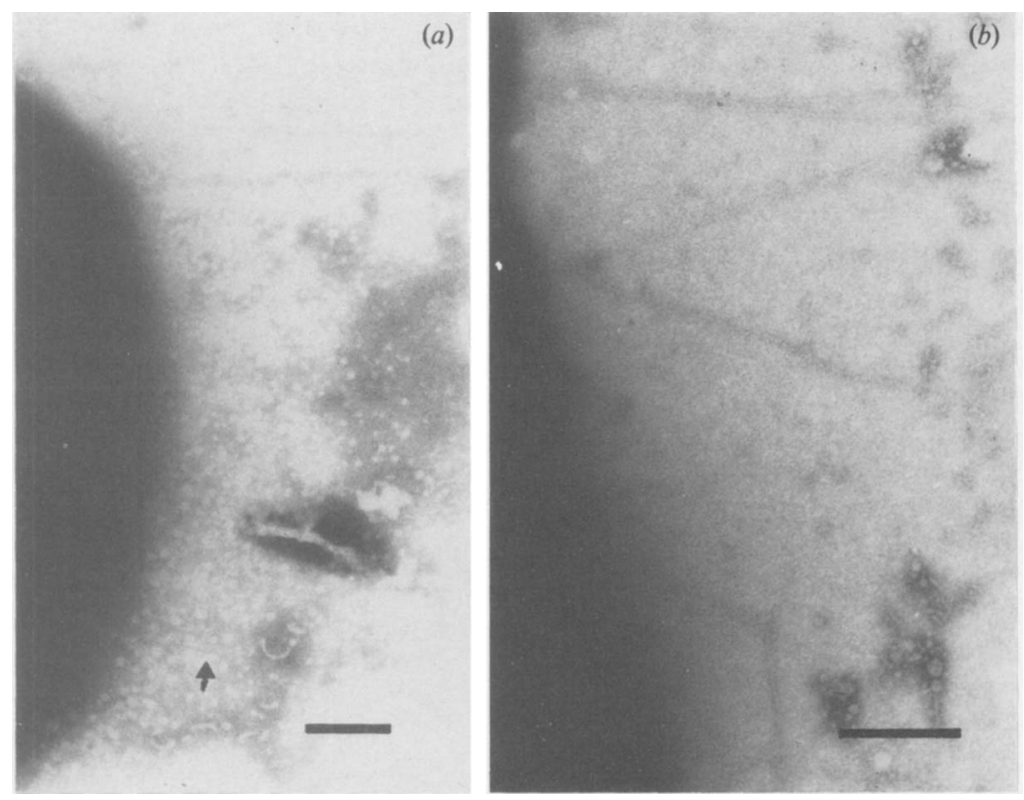

Fig. 4. Negative staining of haemagglutinating strains of G. vaginalis: (a) $102 ;(b) 624$. The arrows point to fimbriae which were found on $<5 \%$ of cells examined. Preparations stained with $2 \%$ sodium silicotungstate. Bars, $0 \cdot 2 \mu \mathrm{m}$.

contrast, the examination of thin sections of the haemagglutinating strains 102 and 624 showed that less than $20 \%$ of the 30 bacteria examined in each case had outer fibrillar structures. However, fine fimbriae were observed on the surface of a few cells (Fig. 3c). Negative staining was also carried out on both these strains; 30 bacteria of each strain were examined and the number showing fimbriae was $<5 \%$. The diameter of the fimbriae was between 3 and $6 \mathrm{~nm}$ (Fig. $4 a, b$ ).

\section{DISCUSSION}

In the present study, the electron microscopic examination of clue cells to reveal the morphological nature of the ligands of presumptive Gardnerella organism in vivo suggests that attachment was mediated by an outer fibrillar coat. The electron microscopic examination of the in vitro attachment of strains of $G$. vaginalis to tissue culture cells and human red cells supports the previous findings that separate adhesins are involved (Scott \& Smyth, 1987). The attachment to tissue culture cells appeared to involve principally an outer fibrillar coat, although occasional fimbriae were observed. The McCoy cell-G. vaginalis interaction appeared to be morphologically identical to the attachment of Gardnerella-like organisms to clue cells. Thus, it would appear that the tissue culture model mirrors the mechanism of attachment in vivo, when bacteria and host cells are in close contact. However, a potential role for fimbriae in initiation of bacteriahost cell interaction cannot be excluded by the current observations. Pronase treatment of tissueculture-adherent strains had previously been shown to render cells non-adherent (Scott \& Smyth, 1987). Thus, the removal of the outer fibrillar coat by pronase treatment provides further evidence for its role in adhesion of $G$. vaginalis.

Thin sections of agglutinated red cells showed that Gardnerella organisms attached by means of thin wiry fimbriae. All the organisms adjacent to red cell surfaces possessed these fimbriae. Although it is possible that extracellular polysaccharide (glycocalyx) could collapse during dehydration into fimbriae-like structures, we do not believe this to be the case in this instance for 
two reasons. Firstly, the fimbriae were predominantly seen on haemagglutinating strains. Secondly, the spatial arrangement of adherent bacteria and red cells was typical of fimbrial haemagglutination demonstrated by ruthenium red staining and observed by electron microscopy (Knutton et al., 1984). While all the bacteria adjacent to red cells bore peritrichous fimbriae, only a minority of the bacteria in thin sections and in negatively stained preparations possessed fimbriae. This is in agreement with the findings of Boustouller et al. (1987), as the strains used in this study had undergone a number of sub-cultures. Morphologically the fimbriae described herein were identical to those previously reported (Johnson \& Davies, 1984; Boustouller et al., 1987).

While this study suggests that the outer fibrillar coat may be of greater importance than fimbriae in attachment to epithelial cells in vivo, the role of fimbriae is not clear. Further work is warranted to clarify the relative roles of the separate adhesins in the pathogenesis of G. vaginalis in bacterial vaginosis.

This work was supported by a grant from the Medical Research Council of Ireland. T. G.S. wishes to thank Professor C. T. Keane for provision of facilities in the Department of Clinical Microbiology, St James's Hospital, Dublin, Ms C. McCormack for assistance with electron microscopy, Mr J. Robinson for photography and the staff of the tissue culture laboratory for their co-operation.

\section{REFERENCES}

Amsel, R., Totten, P. A., SpIegel, C. A., Chen, K. C. S., Eschenbach, D. \& Holmes, K. K. (1983). Non-specific vaginitis. American Journal of Medicine 74, 14-22.

Boustouller, Y. L., Johnson, A. P. \& TAylorRoBinson, D. (1987). Pili on Gardnerella vaginalis studied by electron microscopy. Journal of Medical Microbiology 23, 327-329.

Crisswell, B. S., Stenback, W. A., Black, S. H. \& GARDNER, H. L. (1972). Fine structure of Haemophilus vaginalis. Journal of Bacteriology 109, 930-932.

EASMON, C. S. P. \& Ison, C. A. (1986). Gardnerella vaginalis and bacterial vaginosis. In Medical Microbiology, vol. 4, pp. 53-76. Edited by C. S. F. Easmon \& J. Jeljaszewicz. London: Academic Press.

GreENwOOD, J. R. (1983). Current taxonomic status of Gardnerella vaginalis. Scandinavian Journal of Infectious Diseases (Supplement) 40, 11-14.

Ison, C. A. \& EAsmon, C. S. F. (1985). Studies on the mechanism of adhesion of Gardnerella vaginalis to human erythrocytes. Scandinavian Journal of Nephro$\log y$ (Supplement) 86, 190-193.

Johnson, A. P. \& DAvies, H. A. (1984). Demonstration by electron microscopy of pili of Gardnerella vaginalis. British Journal of Venereal Diseases 60, 196-197.

Knutton, S., Williams, P. H., Lloyd, D. R., Candy, D. C. A. \& MCNEISH, A. S. (1984). Ultrastructural study of adherence to and penetration of cultured cells by two invasive Escherichia coli strains isolated from infants with enteritis. Infection and Immunity 44, 599-608.
MÅRDH, P.-A. \& WESTRÖM, L. (1976). Adherence of bacteria to vaginal epithelial cells. Infection and Immunity 13, 661-666.

PeEters, M. \& Piot, P. (1985). Adhesion of Gardnerella vaginalis to vaginal epithelial cells. Variables affecting adhesion and inhibition by metronidazole. Genitourinary Medicine 65, 391-395.

Reyn, A., Birch-Anderson, A. \& LApage, S. P. (1966). An electron microscope study of thin sections of Haemophilus vaginalis (Gardner \& Dukes) and some possibly related species. Canadian Journal of Microbiology 12, 1125-1136.

ScotT, T. G. \& SMYTH, C. J. (1987). Haemagglutination and tissue culture adhesion of Gardnerella vaginalis. Journal of General Microbiology 133, 19992005.

Scott, T. G., Smyth, C. J. \& Keane, C. T. (1987). In vitro adhesiveness and biotype of Gardnerella vaginalis strains in relation to the occurrence of clue cells in vaginal discharges. Genitourinary Medicine 63, 4753.

Sobel, J. D., Schneider, J., Kaye, D. \& Levison, M. (1981). Adherence of bacteria to vaginal epithelial cells at various stages in the menstrual cycle. Infection and Immunity 32, 194-197.

TAYLOR, E. \& PHILlips, I. (1983). The identification of Gardnerella vaginalis. Journal of Medical Microbiology 16, 83-92. 